\title{
Modulation of COX2 and hTERT expression by Photodynamic Therapy in human colon cancer cells
}

\author{
Christine YOW Li Miu Ngan ${ }^{1}$ \\ Ellie CHU Shihng Meir ${ }^{1}$ \\ ${ }^{1}$ Medical Laboratory Science section, Department of Health Technology and Informatics, \\ The Hong Kong Polytechnic University,
}

Hong Kong

Corresponding author: Christine YOW Li Miu Ngan

Corresponding address: Medical Laboratory Science section, Department of Health Technology and Informatics, The Hong Kong Polytechnic University, Hunghom, Hong Kong SAR.

Email: htcyow@inet.polyu.edu.hk $\quad$ Tel: (852) $34008575 \quad$ Fax: (852) 23624365

\begin{abstract}
Photodynamic therapy (PDT) was employed as a cancer therapy with photosensitizer (PS)-loaded cancer cells, eradicated by the reactive oxygen species after light activation. Cyclo-oxygenase 2 (COX2) is an enzyme expressed in $80 \%$ of colon adenocarcinoma and is one of the targets for effective cancer treatment. There is also uprising evidence that the human telomerase reverse transcriptase ( $h T E R T)$, a catalytic component of telomerase, is reported as a promising indicator for monitoring cancer treatment.

In this study, NPe6 mediated PDT on COX2 induced apoptosis in HT-29 was investigated. The cell cycle changes was analysed by flow cytometry and the $h T E R T$ expression at pre and post PDT was evaluated at transcription level by Taqman real time PCR.

NPe6-PDT in HT-29 cells demonstrated anti-proliferating effect in a drug and light dose dependent manner. LD $_{50}$ was achieved at $16 \mu \mathrm{g} / \mathrm{mL}$ and $2 \mathrm{~J} / \mathrm{cm}^{2}$ at 4 hour-post treatment with a significant down-regulation of COX2 expression at $\mathrm{LD}_{30}$ and $\mathrm{LD}_{50}$ by immunohistochemical staining (IHC) ( $<<0.05$, One-Way ANOVA). Membrane blebbing was detected
\end{abstract}

Photodynamic Therapy: Back to the Future, edited by David H. Kessel, Proc. of SPIE Vol. 7380,

$738065 \cdot$ C 2009 SPIE · CCC code: 1605-7422/09/\$18 · doi: 10.1117/12.823084

Proc. of SPIE Vol. 7380 738065-1 
in over $60 \%$ of cells. $35.2 \%$ of treated cells arrested in S-phase at $\mathrm{LD}_{50}$ after 24 hours by flow cytometry. A 0.25 - and 0.6-fold down-regulation of $h T E R T$ mRNA expression was achieved at $\mathrm{LD}_{30}$ and $\mathrm{LD}_{50}$ respectively by TaqMan real-time PCR.

To summarize, NPe6 mediated PDT down-regulated COX2 expression and triggered cell apoptosis. The hTERT can serve as an indicative marker for monitoring NPe6-PDT cancer treatment efficacy.

\section{KEYWORDS}

Photodynamic Therapy; Colon cancer; NPe6; hTERT; Cyclo-oxygenase 2

\section{INTRODUCTION}

Photodynamic therapy (PDT) is a disease site-specific treatment modality. It involves the local or systemic administration of a photosensitizer followed by irradiating the targeted disease site with non-thermal visible light of appropriate wavelength(s). In the presence of molecular oxygen, the light illumination of photosensitizer and energy transfer can lead to a series of photochemical reactions and generation of reactive oxygen species, and consequently induce apoptosis and necrosis of targeted cells and tissues ${ }^{[1-2]}$.

Mono-L-aspartylchlorin-e6 (NPe6) is one of the promising second-generation photosensitizers. NPe6 is a hydrophilic chlorine derived from chlorophyll a and has exhibited promise at in vitro and in vivo studies due to its excellent photosensitizing properties ${ }^{[3-6]}$. NPe6-PDT has currently applied in advanced-stage clinical trials for cancer treatment due to its great depth-of-light penetration and rapid clearance rate in normal tissues ${ }^{[7-9]}$. However, there are still underlying mechanisms mediated by NPe6-PDT on cancer cells remain unknown.

Colon cancer is the third most prevalence cancer and the second leading cause of cancer related mortality worldwide ${ }^{[10]}$. In Hong Kong, colon cancer is the second most common cancer type and the second death-leading cancer ${ }^{[11]}$. First line treatment for colon cancer is the combination of 5-fluorouracil based adjuvant chemotherapy with improved overall survival. Besides, different standard treatment approaches have been applied for colon cancer including surgery, radiotherapy and chemotherapy ${ }^{[12]}$. Surgery is the most common treatment for all stages of colon cancer; however, it is traumatic to patients. Both chemotherapy and radiotherapy are not cancer-selective causing side-effects. Therefore, PDT can be an alternative treatment modality for colon cancer.

Cyclo-oxygenase (COX) is an enzyme that catalyzes the oxidative conversion of arachidonic acid to prostaglandins, which take place in most tissues under both physiological and pathogenetic condition ${ }^{[13]}$. There are two isoforms of COX enzyme, COX1 and COX2. COX2 is commonly found in normal cells, such as endothelial cells, osteoblasts, 
fibroblasts, and macrophages ${ }^{[14]}$. It is also found that COX2 is over-expressed in about $80 \%$ of human colon cancers ${ }^{[13]}$. Recent research suggested that the COX2 protein facilitates cancer cells growth, invasion and metastasis. Up-regulation of COX2 could promote angiogenesis by initiating cancer cell proliferation and inhibit apoptosis ${ }^{[15]}$. These implying that COX2 pathway could be the potential target for effective colon cancer treatment, thus inhibiting COX2 protein expression may induce apoptotic cell death in colon cancer cells.

Tumor therapies targeting telomerase represent an efficient way to specifically suppress tumor cell growth in telomerase over-expressed tumors. Studies have reported that applications of telomeres and telomerase can act as markers for cancer diagnosis and prognosis, especially through the measurements of the catalytic component of telomerase ( $h T E R T$ - human telomerase reverse transcriptase) as a means of monitoring tumor response to therapy ${ }^{[16]}$. Several reports have revealed that $h T E R T$ could serve as a potential indicator for monitoring tumor treatments in medulloblastoma, uterine sarcoma, ovarian cancer and hepatoma tumor cells ${ }^{[17-20]}$.

In this study, we aimed to investigate the efficacy of NPe6 mediated PDT on colon cancer cells (HT-29). The cell death mechanism, the modulation of COX2 expression and the regulation of hTERT mRNA expression by NPe6-PDT in HT-29 cells were evaluated by cell cycle progression, immuno-histochemical staining (IHC) and the relative quantitation of TaqMan real-time PCR respectively.

\section{METHODOLOGY}

\subsection{Cell cultures and growth conditions}

HT-29 was purchased from American Type Culture Collection (ATCC) is a human colon carcinoma cell line derived from colon epithelial cells obtained from a 44-years-old Caucasian female with colorectal adenocarcinoma. The cells were grown in RPMI 1640 medium supplemented with 10\% fetal bovine serum (FBS) and 1\% antibiotics PSN (50 IU/ml penicillin, $50 \mu \mathrm{g} / \mathrm{ml}$ streptomycin and $100 \mu \mathrm{g} / \mathrm{ml}$ neomycin) (Gibco ${ }^{\mathrm{TM}}$ Invitrogen Corporation, Carlsbad, CA, USA). The cells were incubated at $37.0^{\circ} \mathrm{C}$ with $5 \% \mathrm{CO}_{2}$.

\subsection{Photosensitizer}

Mono-L-aspartylchlorin-e6 (NPe6) was provided by Light Sciences Oncology in powder form. The stock solution $(1 \mathrm{mg} / \mathrm{mL})$ was prepared by dissolving the powder in PBS and then diluted into appropriate concentrations for subsequent experiments and was stored at $4^{\circ} \mathrm{C}$ in dark.

\subsection{Uptake kinetic of NPe6 in HT-29 cells}

Proc. of SPIE Vol. 7380 738065-3 
HT-29 cells $\left(1 \times 10^{6}\right.$ cells per dish) were seeded overnight in $60 \mathrm{~mm}$ culture dishes. After rinsing the cells with phosphate buffered saline (PBS), addition of NPe6 of different concentrations $(0,8,12,16 \mu \mathrm{g} / \mathrm{ml})$ to the cells for different incubation time (0, 2, 4 and 6 hours). The cells were then kept at $37^{\circ} \mathrm{C}$ with $5 \% \mathrm{CO}_{2}$ in dark. Following appropriate incubation time with NPe6, the cells were centrifuged washed with PBS, followed by trypsinization and resuspension in $500 \mu \mathrm{L}$ PBS. The cellular fluorescence emitted by NPe6 was quantified using flow cytometry (FC500, Beckman Coulter, USA). The total events were recorded for each sample and NPe6 concentrations were expressed as the fluorescence intensity.

\subsection{Trypan blue exclusion assay by automated cell viability analyzer}

HT-29 cells $\left(1 \times 10^{6}\right.$ cells/dish) were incubated with NPe6 at $0,2,4,8,12$, and $16 \mu \mathrm{g} / \mathrm{ml}$ in $60 \mathrm{~mm}$ culture plates. The cells were incubated with NPe6 for 4 hours at $37^{\circ} \mathrm{C}$ with $5 \% \mathrm{CO}_{2}$. The sensitized cells were then exposed to light $\left(1 \mathrm{or} 2 \mathrm{~J} / \mathrm{cm}^{2}\right)$ as described previously ${ }^{[21]}$. The phototoxicity was determined at 4 hours post-PDT using an automated cell viability analyzer - Vi-Cell ${ }^{\mathrm{TM}}$ (Beckman Coulter). Control cells without drug and light treatment and dark control (without light irradiation) were included. All results were presented as mean \pm S.D. from 4 independent experiments.

\subsection{Morphological changes of HT-29 cells after NPe6-PDT by microscopic examination}

HT-29 cells were seeded a 96-well plate ( $1 \times 10^{4}$ cells /well), at $\mathrm{LD}_{30}$ and $\mathrm{LD}_{50}$ conditions, and the morphological changes of cells at different time $(0,4,10$ and 24 hours after light treatment) were observed under light microscope (Leica CTR 4000) and images were taken (Leica Application Suite Version 2.4.0.). 1000 cells per sample were counted and the percentage of cells with characterized membrane blebbing was calculated. Six independent experiments in triplicate were conducted.

\subsection{NPe6-PDT induced cell cycle progression in HT-29 cells by flow cytometry}

After NPe6-PDT treatment, 1 X1 $0^{6}$ treated and untreated HT-29 cells were harvested at different time points $(0,4,8,15$ and 24 hours). The cells were trypsinized and washed in cold PBS with $1 \% \mathrm{FBS}$, then fixed in $80 \%$ ethanol at $4^{\circ} \mathrm{C}$ for overnight. After washing the cells in cold PBS with $1 \% \mathrm{FBS}$, the cells were incubated in $250 \mu \mathrm{L}$ of propidium iodide (PI) staining solution ( $40 \mu \mathrm{g} / \mathrm{mL}$ PI and $4 \mu \mathrm{g} / \mathrm{mL}$ RNAse A) for 1 hour at $37^{\circ} \mathrm{C}$ in dark. The fluorescence signal of the cells was quanitated by flow cytometry (FC500, Beckman Coulter, USA). Modfit LT 2.0 software was used for cell cycle analysis.

\subsection{NPe6-PDT modulated COX2 protein expression by immunohistochemical (IHC) staining}

The COX2 protein expression on the HT-29 cells response to NPe6-PDT was demonstrated using COX2 antibody and Avidin Biotin Complex (ABC) Immunohistochemical (IHC) DAB staining (VECTOR ABC Elite Kit). 
Diaminobenzidine tetrahydrochloride (DAB) acted as chromogen to localize peroxidase in cells as reddish brown precipitate. Briefly, the treated $\left(\mathrm{LD}_{30}\right.$ and $\left.\mathrm{LD}_{50}\right)$, untreated and dark control cells were harvested at 4-hour-post-PDT. Cells were re-suspended in $500 \mathrm{ul}$ RPMI. The cell suspension were loaded and spin at 800rpm for 3 minutes, after disassemble the cassette, the slides were air dried, and fixed in cold methanol for 20 minutes at $-20^{\circ} \mathrm{C}$. All the procedures were followed as described by the manufacturer. Internal negative control was included using PBS instead of the primary COX2 antibody.

After the IHC staining, the slides were observed under light microscope (Nikon ECLIPSE 80i). A Color Mosaic 14.2 camera and Spot Insight 4.6 acquisition software (Diagnostic Instruments, Sterling Heights, MI) were used to capture the images under 100X. The images were analyzed by an image analysis software (i-Solution, IMT, Daejeon, Korea). The Hscore system was used to evaluate the DAB color intensity developed in cells by grading as 0 (negative or very weak staining), 1+ (weak staining), 2+ (distinct staining), or 3+ (intensive or strongly staining). The percentages of cells in the four categories were recorded. For each slide, the H-Score value was calculated by summing the percentages of cells (P) multiplied by the weighted intensity and the maximum value of $\mathrm{H}$-score was $300^{[22-23]}$. All results were presented as mean \pm S.D. from 3 independent experiments.

\subsection{Quantitation of $h T E R T$ mRNA expression mediated by NPe6-PDT using TaqMan real-time PCR}

A more sensitive real-time PCR analysis to $h T E R T$ mRNA quantitation in HT-29 cells after NPe6-PDT was performed by pre-designed gene-specific primers and probe sets of TaqMan ${ }^{\circledR}$ Gene Expression Assay for $h T E R T$ and for GAPDH (as an endogenous control) together with the TaqMan ${ }^{\circledR}$ Universal PCR Master Mix (without AmpErase UNG) using a 7500 Real-Time PCR System (Applied Biosystems, CA, USA). In brief, the total RNA of the controls and the treated samples (dark control, $\mathrm{LD}_{30}$ and $\mathrm{LD}_{50}$ ) were extracted as described above using the High Pure RNA Isolation kit (Roach Diagnostics, Switzerland). The cDNA were reverse-transcribed using the RevertAidTM H Minus First Strand cDNA synthesis kit (Fermentus, Life Sciences, Canada). For TaqMan assay, a $20 \mu \mathrm{l}$ PCR reaction mixture of each sample contained TaqMan universal master mix, each primer pair, probes, and a $20 \mathrm{ng}$ cDNA template. Following the denaturation, annealing and extension procedures of PCR cycling procedures, fluorescent data were collected. A total of eight reaction tubes were required for each sample, four replicates for $h T E R T$ and another four for GAPDH. The above reaction mixtures and PCR conditions were used as recommended by the manufacturer. The comparative threshold cycle $\left(\mathrm{C}_{\mathrm{T}}\right)$ method $\left(\triangle \Delta \mathrm{C}_{\mathrm{T}}\right.$ method) was used to calculate the amount of $h T E R T$ mRNA that normalized to the endogenous reference (i.e. $G A P D H)$.

\subsection{Data analysis}

The GraphPad Prism Version 4.0 was used to analyze the results obtained. All data were presented as mean and standard error (S.D.). $P$ value smaller than $0.05(P<0.05)$ was considered significant. 


\section{RESULTS}

\subsection{Uptake kinetics of NPe6 by HT-29 cells}

The uptake of NPe6 was determined by the qantitation of the intracellular fluorescence intensity using flow cytometry, since the intracellular fluorescent intensity of NPe6 inside the HT-29 cells was directly proportional to the amount of NPe6 uptake by the cancer cells. From the results in Figure 1, the uptake of NPe6 in HT-29 cells was found to be timeand drug-dosage dependent. Maximum uptake was obtained at 6 hours, while the fluorescence intensity reached maximal of $12 \mu \mathrm{g} / \mathrm{mL}$, and remained in plateau with $16 \mu \mathrm{g} / \mathrm{mL}$ of NPe6.

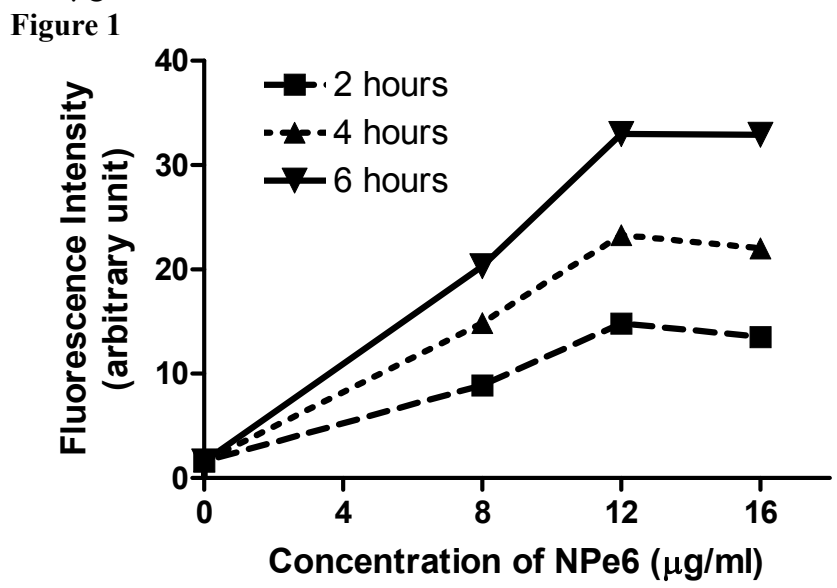

Figure 1 Uptake of NPe6 by HT-29 colon cancer cells

The HT-29 cells were incubated with different concentrations of NPe6 at 8,12 and $16 \mu \mathrm{g} / \mathrm{mL}$ under different incubation times at 0,2 , 4 and 6 hours. The uptake of the NPe6 by HT-29 was in a time-dependent and drug-dosage-dependent manner. Data were expressed as mean $\pm \mathrm{SD}$ of three independent experiments.

\subsection{Phototoxicity of NPe6-PDT on HT-29 cells}

Phototoxicity of NPe6-PDT on HT-29 cells was determined after 4 hours incubation time by the trypan blue exclusion assay using the Vi-Cell ${ }^{\mathrm{TM}}$ cell viability analyzer (Beckman Coulter, USA). Figure 2 showed the phototoxicity of HT-29 cells treated with NPe6-PDT at different concentrations $(2,4,8$, and $16 \mu \mathrm{g} / \mathrm{ml})$, and different light doses $\left(1\right.$ and $\left.2 \mathrm{~J} / \mathrm{cm}^{2}\right)$. Dark control (without light treatment) and control (without both NPe6 and light treatment) were included. The results showed that the dark toxicity was negligible while significant phototoxicity was observed in NPe6-PDT treated cells in drug- and light-dosage dependent manners. Lethal doses were investigated that $\mathrm{LD}_{30}$ was obtained with $8 \mu \mathrm{g} / \mathrm{ml}$ of NPe6 at $2 \mathrm{~J} / \mathrm{cm}^{2}$; while $\mathrm{LD}_{50}$ was obtained at $16 \mu \mathrm{g} / \mathrm{ml}$ of NPe6 at $2 \mathrm{~J} / \mathrm{cm}^{2}$, which were employed for subsequent experimental investigation. 


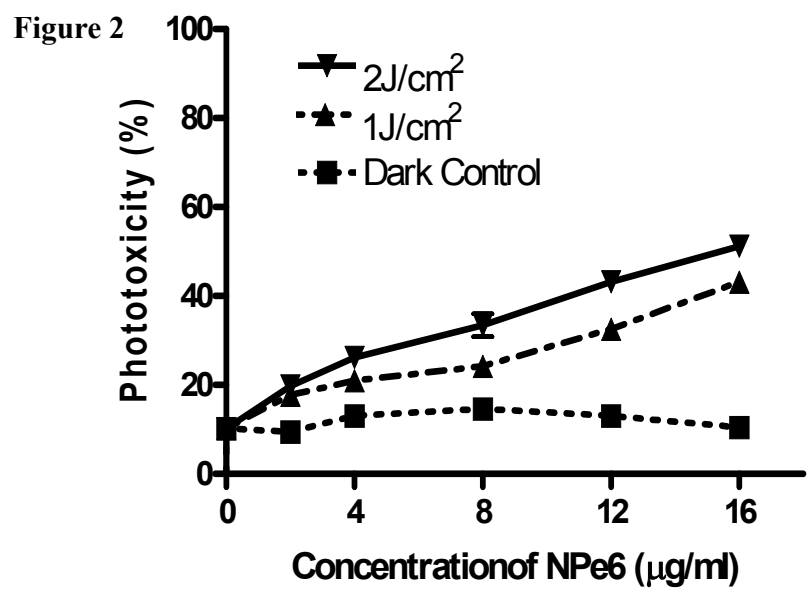

Figure 2 Phototoxicity of NPe6-PDT on HT-29 cells

The cells were incubated for 4 hours with different NPe6 concentrations $(0,2,4,8$, and $16 \mu \mathrm{g} / \mathrm{ml})$ and illuminated with different light doses $\left(0,1\right.$ and $\left.2 \mathrm{~J} / \mathrm{cm}^{2}\right)$. Phototoxicity was determined by Vi-cell analysis followed by PDT. It was found that the percentage of phototoxicity increased significantly with increasing NPe6 concentrations and light doses ( $<<0.01$, two-way ANOVA). The phototoxicity was in drug- and light-dosage dependent manners. All the results were presented as mean \pm SD in duplicate from four independent experiments.

\subsection{Microscopic Examination of Morphological Changes induced by NPe6-PDT in HT29cells}

Cell shrinkage and membrane blebbing were the typical characteristics of apoptotic cells. The microscopic examination was employed to qualify any morphological changes of the cells after NPe6-PDT. At LD 30 -hours post-PDT, over 30\% cell shrinkage occurred; whereas at $\mathrm{LD}_{50}$ 4-hours post-PDT, there were over $60 \%$ of cells with typical membrane blebbing characteristics. The data indicated were from four individual experiments in triplicate. These results showed that NPe6-PDT induced apoptotic cell death in HT-29 cells (data not showed).

\subsection{Cell Cycle Analysis by Flow Cytometry}


For cell cycle analysis, percentage of HT-29 cells in S phase increased when the cells were treated at $\mathrm{LD}_{30}$ and $\mathrm{LD}_{50} 24$ hour-post-PDT (Table 1). At $\mathrm{LD}_{30}$, the S-phase was shifted from $20.53 \%$ to $25.24 \%$; while at $\mathrm{LD}_{50}$, the S-phase was shifted from $20.53 \%$ to $35.20 \%$. The percentage of cells in $\mathrm{G} 0 / \mathrm{G} 1$ phase decreased at the same time. At $\mathrm{LD}_{30}$, the $\mathrm{G} 0 / \mathrm{G} 1$ phase was shifted from $60.39 \%$ to $52.13 \%$; while at $\mathrm{LD}_{50}$, the $\mathrm{G} 0 / \mathrm{G} 1$ phase was shifted from $60.39 \%$ to $40.76 \%$. The data indicated that the NPe6-PDT induced S-Phase arrest and decreased G0/G1 phase in HT-29 cells.

Table 1: Percentage of cell cycle phases after NPe6-PDT in HT-29 cells

At $\mathrm{LD}_{50}$, NPe6-PDT induced S-Phase arrest and decreased G0/G1 phase of the cell cycle. Data presented were from three independent experiments in triplicate.

\begin{tabular}{lcccc}
\hline \multirow{2}{*}{ Samples } & \multicolumn{4}{c}{ Cell cycle phases (\%) } \\
\cline { 2 - 5 } & Sub G1 & G0/G1 & S & G2/M \\
\hline Control & $0.14 \pm 0.03$ & $63.39 \pm 0.04$ & $20.53 \pm 0.05$ & $16.08 \pm 0.08$ \\
Dark control & $0.07 \pm 0.02$ & $61.03 \pm 0.06$ & $23.16 \pm 0.17$ & $15.08 \pm 0.11$ \\
$\mathrm{LD}_{30}\left(8 \mathrm{ug} / \mathrm{ml}, 2 \mathrm{~J} / \mathrm{cm}^{2}\right)$ & $0.26 \pm 0.21$ & $52.13 \pm 0.12$ & $25.24 \pm 0.03$ & $22.63 \pm 0.09$ \\
$\mathrm{LD}_{50}\left(16 \mathrm{ug} / \mathrm{ml}, 2 \mathrm{~J} / \mathrm{cm}^{2}\right)$ & $0.77 \pm 0.33$ & $40.76 \pm 0.42$ & $35.20 \pm 0.28$ & $23.81 \pm 0.14$ \\
\hline
\end{tabular}

\subsection{NPe6-PDT down-regulated COX2 protein expression in HT-29 cells}

In the study, the COX2 protein expression modulated by NPe6-PDT on HT-29 cells was investigated by the IHC staining. The images acquired and analyzed using $\mathrm{H}$-Score systems. At $\mathrm{LD}_{50}$, the COX2 protein expression was significantly down-regulated by NPe6-PDT (One-way ANOVA, $\mathrm{p}<0.05$ ) when compared with the control and dark control cells (Figure 3).

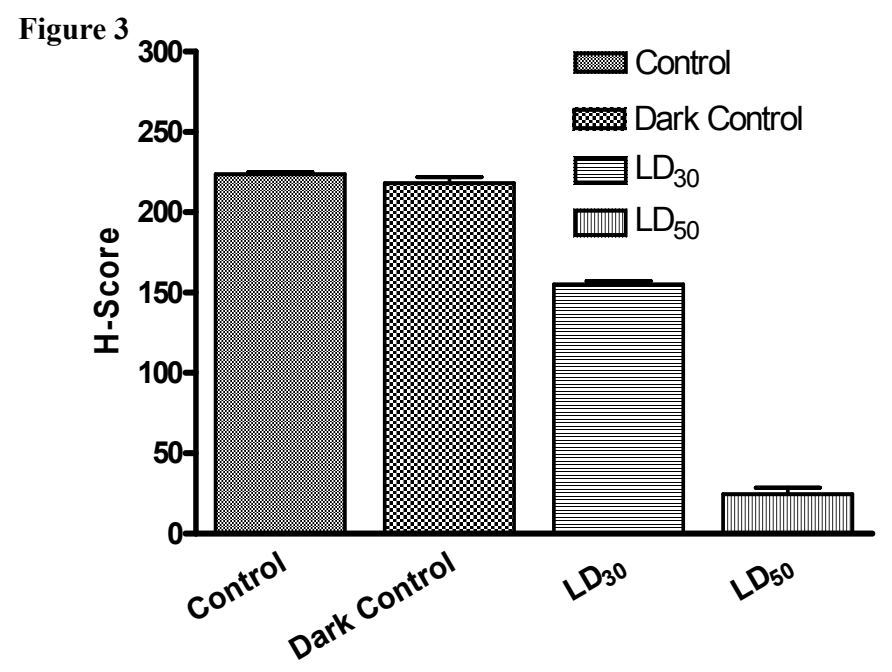


Figure 3 Down-regulation of COX2 protein expression by NPe6-PDT in HT-29 cells

The COX2 protein expression was significantly down-regulated with the H-score decreased from 200 to 20 in the control cells and $\mathrm{LD}_{50}$ respectively after NPe6-PDT in HT-29 cells (One-way ANOVA, $\mathrm{p}<0.05$ ). Data showed as mean $\pm \mathrm{SD}$ in four independent experiments in triplicate.

\subsection{Modulation of $h T E R T$ mRNA expression by NPe6-PDT in HT-29 cells}

The NPe6-PDT modulated hTERT mRNA expression in HT-29 cells was quantitated by TaqMan real-time PCR. There was an intensive down-regulation of $h T E R T$ mRNA expression at LD $_{50}$ (One-way ANOVA; p $<0.01$ ) in HT-29 cells, indicating that this colon cancer cells were sensitive to the PDT treatment by NPe6 at sub-lethal doses (Figure 4). This implied that the $h T E R T$ could serve as an indicative marker for monitoring NPe6-PDT cancer treatment efficacy in colon cancer.

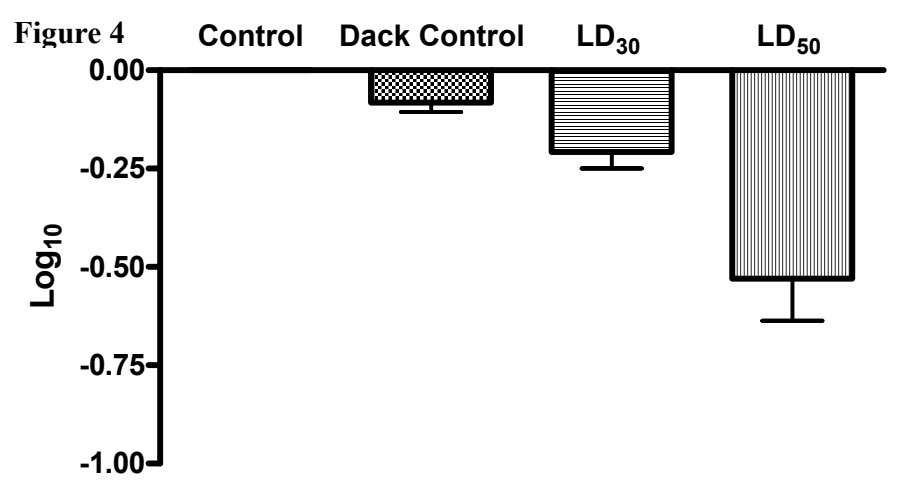

Figure 4 Down-regulation of $h T E R T$ mRNA expression by NPe6-PDT using TaqMan real-time-PCR

After normalization with corresponding GAPDH mRNA expression of each sample in HT-29 cells, down-regulation of $h T E R T$ mRNA expression was mediated by NPe6-PDT at both $\mathrm{LD}_{30}$ and $\mathrm{LD}_{50}$ using TaqMan real-time-PCR (One-way ANOVA, $<<0.01$ ). When compared with the control, there were about 0.6-fold reduction of hTERT mRNA expression obtained at LD 50 after NPe6-PDT. Concentrations of the mRNA expressions were represented in $\log _{10}$.

\section{DISCUSSION}

Studies have demonstrated that NPe6-PDT was effective for cutaneous tumor cell disruption in vitro and in vivo ${ }^{[6,24]}$. Due to the improved properties of NPe6, NPe6-PDT has also being applied clinically with promising results in skin and lung cancer patients ${ }^{[7,25]}$. However, the detailed cell death mechanisms of NPe6-PDT in tumor cells remained to be explored.

Our study aims to elucidate the cell death mechanism induced by NPe6-PDT in a colon carcinoma cell line in vitro. In summary, this study reveals an effective and responsive PDT treatment of a colon carcinoma cell line (HT-29) with NPe6. Encouraging evidence is shown in this study that NPe6-PDT not only acted as a COX2 inhibitor, but also downregulated the $h T E R T$ mRNA expression, which can be a marker for PDT monitoring. 
The HT-29 colon tumor cells were responsive to NPe6-PDT in the drug- and light-dose-dependent manner for the NPe6 uptake kinetics (Figure 1) and the NPe6-PDT mediated efficacy (Figure 2). There is only negligible dark toxicity. It was reported that the effectiveness of NPe6 was related to plasma level and progressive uptake of NPe6 by the target cells could be obtained over several hours implying that high plasma concentrations of this photosensitizer were associated with toxicity ${ }^{[26-27]}$. Therefore, the lower concentrations of NPe6 $(8 \mu \mathrm{g} / \mathrm{ml}$ and $16 \mu \mathrm{g} / \mathrm{ml})$ at 4 hours sensitization were recommended in the subsequent study to potentiate the effects of the drug on the proposed colon cells.

For the determination of cell death mechanism, our results revealed that there was $30 \%$ to $60 \%$ morphological cell shrinkage at 4 hour-post NPe6-PDT in HT-29 cells by the microscopic examination (data not shown). Confirmation of the apoptotic events and cell cycle progression mediated by NPe6-PDT in HT-29 cells were further quantitated by propidium iodide staining using flow cytometry. Our pioneer report demonstrated that NPe6-PDT induced S phase arrest of cell cycle in HT-29 cells (Table 1) indicating the NPe6-PDT inhibited the tumor cells to undergo DNA synthesis and chromosome replication, in turn prohibited tumor cell division and proliferation. However, changes in cell cycle proteins, such as cyclin and cyclin dependent kinases, deserved to be investigated at pre- and post-NPe6-PDT.

From the results in Table 1, apoptotic events could not be quantitated in the sub-G1 phase of the NPe6-PDT-treated cells thus apoptosis might not the dominant cell death mechanism mediated by NPe6-PDT in HT-29 cells. This result was in line with previous finding that NPe6, being a lysosomal photosensitizer, although, caused photodamage in murine tumor models but lack of a more substantial apoptotic response to PDT when lysosomes were the initial PDT target ${ }^{\text {[28-29] }}$. Therefore, NPe6-PDT modulated apoptotic protein expression related to lysosomes, such as caspase 3, could further be studied.

As over $80 \%$ of human colon tumors with COX2 over-expression, this study also evaluated the regulation of COX2 protein expression by NPe6-PDT in HT-29 cells ${ }^{[13]}$. Ferrario et al demonstrated that down-regulation of COX2 expression by PDT enhanced the efficacy of PDT in tumor killing ${ }^{[30]}$. In our study, there was a significant 4-fold downregulation of COX2 protein expression by NPe6-PDT in HT-29 cells at $\mathrm{LD}_{50}$ (Figure 3) indicating the inhibition of COX2 protein expression by NPe6-PDT could further prohibit tumor cell growth and thus might enhance the tumoricidal effects of PDT in colon tumors.

Having elucidated the cell cycle progression and down-regulation of COX2 expression by NPe6-PDT on HT-29 cells, another well-known marker, $h T E R T$ mRNA expression for monitoring PDT treatment was quantitatively studied at preand post-NPe6-PDT in the proposed cells. Our results significantly demonstrated there was a 0.6-fold in $h T E R T$ mRNA 
expression at $\mathrm{LD}_{50}$ post-PDT when compared with the control cells and GAPDH acted as the internal control (Figure 4). This was similar to our previous findings that hexyl-ALA-PDT could also reduce the hTERT mRNA expression in both uterine sarcoma cell lines ( $>50 \%$ reduction) and medulloblastoma cell line (30\% reduction) ${ }^{[17-18]}$. The results suggested that $h T E R T$ mRNA expression could be a marker for monitoring NPe6-PDT in colon tumors in future clinical setting.

\section{CONCLUSION}

In conclusion, NPe6-PDT is effective for HT-29 colon cancer cells with its ability to induce phototoxicity to the cancer cells and causing cell cycle arrest in S-phase. Although, apoptosis was not the dominant cell death mechanism triggered by NPe6-PDT in HT-29 cells, the COX2 and hTERT mRNA expression were down-regulated by NPe6-PDT suggesting NPe6-PDT pave the way in future alternative treatment for colon cancers in clinical settings.

\section{ACKNOWLEDGEMENT}

This study was supported by the funding from the Hong Kong Polytechnic University (HTI/HKPolyU/87NT).

\section{REFERENCES}

[1] Qiang, Y.G., Yow, C.M.N., and Huang, Z., "Combination of photodynamic therapy and immunomodulation: current status and future trends," Med Res Rev, 28(4), 632-644 (2008).

[2] MacDonald, I.J. and Dougherty, T.J., "Basic principle of photodynamic therapy," J Porphyrins Phthalocyanines. 5, 105-129 (2001).

[3] Usuda, J., Kato, H., Okunaka, T., Furukawa, K., Tsutsui, H., Yamada, K., Suga, Y., Honda, H., Nagatsuka, Y. and Ohira, T., "Photodynamic therapy (PDT) for lung cancers," J Thorac Oncol. 5, 489-493 (2006)

[4] Kaneko, T., Chiba, H., Yasuda, T. and Kusama, K., "Detection of photodynamic therapy-induced early apoptosis in human salivary gland tumor cells in vitro and in a mouse tumor model," Oral Oncol. 40, 787-92 (2004)

[5] Song, L.M.W., Wang, K.K. and Zinsmeister, A.R., "Mono-L-aspartyl chlorin e6 (NPe6) and hematoporphyrin derivative $(\mathrm{HpD})$ in photodynamic therapy administered to a human cholangiocarcinoma model," Cancer. 82, 421427 (1998).

[6] Ferrario, A., Kessel, D. and Gomer, C.J., "Metabolic properties and photosensitizing responsiveness of mono-Laspartyl chlorin e6 in a mouse tumor model," Cancer Res. 52, 2890-2893 (1992).

[7] Chan, A.L, Juarez, M., Allen, R., Viols, W. and Albertson, T., "Pharmacokinetics and clinical effects of mono-Laspartyl chlorin e6 (NPe6) photodynamic therapy in adult patients with primary or secondary cancer of the skin and mucosal surfaces," Photodermatol Photoimmunol Photomed. 21, 72-78 (2005).

[8] Lustig, R.A., Vogl, T.J., Fromm, D., Cuenca, R., His, R.A., D’Cruz, A.K., Krajina, Z., Turic, M., Singhal, A. and Chen, J.C., "A multicenter phase I safety study of intratumor photoactivation of talaporfin sodium in patients with refractory solid tumors," Cancer. 98, 1767-1771 (2003). 
[9] Taber, S.W., Fingar, V.H., Coots, C.T. and Wieman, T.J., "Photodynamic therapy using mono-L-aspartyl chlorin e6 (NPe6) for the treatment of cutaneous disease: a phase I clinical study," Clin Cancer Res. 4, 2741-2746 (1998).

[10]Hector, S. and Prehn, J.H.M., "Apoptosis signaling proteins as prognostic biomarkers in colorectal cancer: a review,” Biochim Biophys Acta. 1795, 117-129 (2009).

[11] Hong Kong Cancer Registry, "Statistics for Colorectal Cancer Hong Kong 2006”, (2006).

[12] Grothey, A., "Biological therapy and other novel therapies in early-stage disease: are they appropriate?," Clin Cancer Res. 13(22 Suppl), 6909s-6912s (2007).

[13] Brown, J.R. and DuBois, R.N., "COX2: A Molecular Target for Colorectal Cancer Prevention,” J Clin Oncol. 23, 2840-2855 (2005).

[14] Ota, S., Bamba, H., Kato, A., Kawamoto, C., Yoshida, Y. and Fujiwara, K., "COX2, prostanoids and colon cancer," Aliment Pharmacol Ther. 16, 102-106 (2002).

[15] Yamashita, K., Arimura, Y., Shimizu, H., Takahashi, H., Endo, T., Imai, K. and Yamano, H., "Increased cyclooxygenase-2 expression in large flat colorectal tumors," J Gastroenterol. 38, 69-73 (2003).

[16] Kelland, L.R., “Telomerase: biology and phase I trials,” Lancet Oncol. 2, 95-102 (2001).

[17] Chu, E.S., Wong, T.K. and Yow, C.M., "Photodynamic effect in medulloblastoma: downregulation of matrix metalloproteinases and human telomerase reverse transcriptase expressions," Photochem Photobiol Sci. 7, 76-83 (2008).

[18] Chu, E.S.M., Shi, M., Ho, R.J.Y. and Yow, C.M.N., "Effects of photoactivated 5-aminolevulinic acid hexylester on MDR1 over-expressing human uterine sarcoma cells," Toxicology Lett. 181, 7-12 (2008).

[19] Sun, P.M., Wei, L.H., Luo, M.Y., Liu, G., Wang, J.L., Mustea, A., Konsgen, D., Lichtenegger, W. and Sehouli J., "The telomerase activity and expression of hTERT gene can serve as indicators in the anti-cancer treatment of human ovarian cancer,” Eur J Obstet Gynecol Reprod Biol. 130, 249-257 (2007).

[20] Guo, Q.L., Lin, S.S., You, Q.D., Gu, H.Y., Yu, J., Zhao, L., Qi, Q., Liang, F., Tan, Z. and Wang, X., "Inhibition of human telomerase reverse transcriptase gene expression by gambogic acid in human hepatoma SMMC-7721 cells," Life Sci. 78, 1238-1245 (2006).

[21] Yow, C.M.N., Chen, J.Y., Mak, N.K., Cheung, N.H. and Leung, A.W.N., "Cellular uptake, subcellular localization and photodamaging effect of temoporfin (mTHPC) in nasopharyngeal carcinoma cells: comparison with hematoporphyrin derivative (HPD)," Cancer Lett. 157(2), 123-131 (2000).

[22] Celik-Ozenci, C., Ustunel, I., Erdogru, T., Seval, Y., Korgun, E.T., Baykara, M. and Demir, R., "Ultrastructural and immunohistochemical analysis of rat uroepithelial cell junctions after partial bladder outlet obstruction and selective COX2 inhibitor treatment," Acta histochemica. 107, 443-451 (2006). 
[23] van Diest, P.J., van Dam, P., Henzen-Logmans, S.C., Berns, E., van der Burg, M.E.L., Green, J. and Vergote, I., “A scoring system for Immunohistochemical staining: consensus report of the task force for basic research of the EORTC-GCCG,” J Clin Pathol. 50, 801-804 (1997).

[24] Nakamura, H., Suzuki, Y., Takeichi, M., Saito, T., Takayama, M. and Aizawa, K., "Morphological evaluation of the antitumor activity of photodynamic therapy (PDT) using mono-L-aspartyl chlorine e6 (NPe6) against uterine cervical carcinoma cell lines,” Int J Gynecol Cancer. 12, 177-186 (2002).

[25] Metz, J.M. and Friedberg, J.S., "Endobronchial photodynamic therapy for the treatment of lung cancer," Chest Surg Clin North Am. 11, 829-839 (2001).

[26] Kessel, D., "Determinants of photosensitization by mono-L-aspartyl chlorin e6," Photochem Photobiol. 49, 447-452 (1989).

[27] Roberts, W.G. and Berns, M.W., "In-vitro photosensitization. I. Cellular uptake and subcellular localization of mono-L-aspartyl chlorin e6, chloroaluminum sulfonated phthaloxyanine and photofrin II," Lasers Surg Med. 9, 90 101 (1989).

[28] Wong, S., Luna, M., Ferrario, A. and Gomer, C.J., "CHOP activation by photodynamic therapy increases treatment induced photosensitization," Lasers Surg Med. 35(5), 336-341 (2004).

[29] Kessel, D., Luo, Y., Mathieu, P. and Reiners, J.J., "Determinants of the apoptotic response to lysosomal photodamage," Photochem Photobiol. 71(2), 196-200 (2000).

[30] Ferrario, A., von Tiehl, K., Wong, S., et al, "Cyclooxygenase-2 inhibitor treatment enhances photodynamic therapymediated tumor response," Cancer Res. 62, 3956-3961 (2002).

Proc. of SPIE Vol. $7380738065-13$ 